\title{
Projekt ustawy Karta Praw Podatnika Z UZASADNIENIEM
}

\section{Ustawa \\ z dnia \\ Karta praw podatnika}

\section{Preambuła}

Mając na względzie rolę podatków w demokratycznym państwie prawnym i uznając, że państwo i samorząd terytorialny są zobowiązane do dbałości o prawa podmiotów, które umożliwiają ich działanie, ponosząc ciężary i świadczenia publiczne, w tym w szczególności podatki, stanowi się Kartę Praw Podatnika. Celem Karty jest zapewnienie należytej ochrony praw podatników, w tym poprzez odpowiednie wyważenie interesu publicznego i prywatnego w prawie podatkowym oraz podniesienie świadomości społecznej praw podatnika.

\section{Rozdział 1 \\ Postanowienia wstępne}

Art. 1

\section{Zakres podmiotowy ustawy}

1. Unormowania ustawy stosuje się do podatników, a także innych podmiotów, których prawa i obowiązki są regulowane przepisami prawa podatkowego, w tym w szczególności płatników, inkasentów, osób trzecich odpowiedzialnych za zaległości podatkowe oraz następców prawnych. 
2. Ilekroć w ustawie jest mowa o podatniku rozumie się przez to również inne podmioty, o których mowa w ust. 1.

Art. 2

Obowiązek informacyjny organów podatkowych w zakresie praw podatnika

1. Organy podatkowe publikują na swoich stronach Internetowych Kartę Praw Podatnika.

2. Wszczynając postępowanie podatkowe, kontrolę podatkową lub kontrolę celno-skarbową organy podatkowe doręczają podatnikowi egzemplarz Karty Praw Podatnika.

\section{Rozdział 2 \\ Prawo do dobrego prawodawstwa podatkowego}

Art. 3

Obowiązek odpowiedniego wyważenia interesu publicznego i interesu prywatnego $\mathrm{w}$ prawie podatkowym

1. Prawo podatkowe tworzone jest $\mathrm{z}$ poszanowaniem konstytucyjnie określonych praw i wolności ekonomicznych, z uwzględnieniem zarówno interesu publicznego jak i prywatnego, w tym w szczególności poprzez odpowiednie konsultowanie projektów przepisów prawa podatkowego.

2. Wszystkie projekty przepisów prawa podatkowego, w tym w szczególności projekty poselskie, są poddawane konsultacjom z udziałem podatników, przedstawicieli organizacji społecznych, samorządowych i gospodarczych oraz samorządów zawodowych.

Art. 4

\section{Pewność prawa podatkowego}

1. Podatnik ma prawo do ochrony praw nabytych i interesów w toku.

2. Należy zapewnić odpowiedni czas między ogłoszeniem przepisu prawa podatkowego a jego wejściem w życie (vacatio legis), umożliwiający podatnikowi dostosowanie się do nowych unormowań.

3. Prawo nie działa wstecz, chyba że na korzyść podatnika.

4. Organy podatkowe bez uzasadnionej przyczyny nie odstępują od utrwalonej praktyki rozstrzygania spraw w takim samym stanie faktycznym i prawnym.

5. Podatnik ma prawo do stabilizacji stosunków prawnych przez przedawnienie następujące w rozsądnym i przewidywalnym czasie. 
Art. 5

\section{Jawność prawa podatkowego}

1. Minister właściwy do spraw finansów publicznych ma obowiązek urzędowej publikacji ujednoliconych tekstów aktów prawnych z zakresu prawa podatkowego.

2. Przepisy prawa podatkowego są tworzone i przyjmowane w ramach jawnych procedur prawodawczych, co oznacza także publikowanie rządowych założeń i projektów przepisów prawa podatkowego z odpowiednim wyprzedzeniem $\mathrm{w}$ celu poddania ich konsultacjom publicznym i zapewnienie jawności debat parlamentarnych oraz debat w organach stanowiących jednostek samorządu terytorialnego.

Art. 6

\section{Komunikatywność prawa podatkowego}

1. Podatnik ma prawo do jasnego i zrozumiałego prawa podatkowego.

2. Organy podatkowe wspierają podatnika w wykonywaniu jego obowiązków i korzystaniu z praw, w tym w szczególności udzielając informacji o prawidłowym sposobie rozumienia i stosowania przepisów prawa podatkowego.

3. Zastosowanie się przez podatnika do informacji udzielonej przez organ podatkowy $\mathrm{w}$ formie przewidzianej w przepisach nie może mu szkodzić, w tym w szczególności nie może być podstawą do zastosowania sankcji podatkowych, karnych i karnych skarbowych oraz żądania zapłaty odsetek od zaległości podatkowych.

4. Niedające się usunąć wątpliwości co do treści normy prawa podatkowego rozstrzyga się na korzyść podatnika.

5. Niezrozumiały przepis prawa podatkowego nie może być podstawą zastosowania sankcji podatkowych, karnych i karnych skarbowych.

\section{Rozdział 3}

Prawo do zapłaty podatku w wysokości wynikającej z ustaw podatkowych

Art. 7

\section{Zapłata podatku w prawidłowej wysokości i zwrot należnej nadpłaty}

1. Podatnik ma prawo do zapłaty podatku w wysokości wynikającej z ustaw podatkowych.

2. Podatnik ma prawo do korekty złożonych deklaracji. 
3. Podatnik ma prawo do zainicjowania postępowania w celu stwierdzenia, czy doszło do powstania nadpłaty.

4. Podatnik ma prawo do otrzymania zwrotu nadpłaty w rozsądnym terminie.

\section{Art. 8}

\section{Ulgi i zwolnienia}

1. Podatnik ma prawo do ulg i zwolnień, których zastosowanie zależy od spełnienia przesłanek jasno określonych w przepisach.

2. Prawo do ulg i zwolnień podatkowych oraz korzystania z innych przewidzianych przepisami możliwości obniżenia wysokości podatku przysługuje podatnikowi w każdym czasie, chociaż nie dłużej niż przez okres odpowiadający przedawnieniu zobowiązania podatkowego.

3. Podatnik ma prawo do ulgi w zapłacie zobowiązań podatkowych lub do umorzenia zaległości podatkowej, jeśli przemawiają za tym wartości konstytucyjne, w szczególności ochrona godności jednostki, minimum egzystencji, ochrona rodziny albo zasada ochrony źródeł podatku.

\section{Rozdział 4 \\ Prawo do domniemania rzetelności i dobrej wiary}

\section{Art. 9 \\ Domniemanie rzetelności wykonania obowiązków wynikających $\mathrm{z}$ przepisów prawa podatkowego}

1. Domniemywa się prawidłowość wykonania przez podatnika obowiązków wynikających z przepisów prawa podatkowego, chyba że zostanie wykazane przez organ podatkowy, że obowiązki nie zostały prawidłowo wykonane.

2. Domniemywa się prawidłowość deklaracji złożonej przez podatnika, chyba że zostanie wykazane przez organ podatkowy, że deklaracja jest nieprawidłowa albo deklaracja zostanie skutecznie skorygowana.

3. Niedające się usunąć wątpliwości co do stanu faktycznego rozstrzyga się na korzyść podatnika.

Art. 10

\section{Domniemanie dobrej wiary}

Domniemywa się dobrą wiarę podatnika, chyba że zostanie wykazane przez organ podatkowy, że podatnik działał w złej wierze. 


\section{Rozdział 5 \\ Prawo do prywatności}

\section{Art. 11 \\ Ochrona danych i dostępu do nich}

1. Organy podatkowe gromadzą i przetwarzają jedynie takie informacje dotyczące podatnika i jego spraw, które pozostają w związku z wykonaniem obowiązków i korzystaniem z praw wynikających z przepisów prawa podatkowego.

2. Organy podatkowe wykorzystują informacje dotyczące podatnika i jego spraw tylko w zakresie dozwolonym prawem.

3. Podatnik ma prawo dostępu do informacji dotyczących jego i jego spraw gromadzonych i przetwarzanych przez organy podatkowe oraz do informacji o sposobie i zakresie ich wykorzystania.

Art. 12

\section{Zachowanie informacji w tajemnicy}

1. Organy podatkowe zachowują informacje dotyczące podatnika i jego spraw w tajemnicy.

2. Organy podatkowe przekazują innym podmiotom informacje dotyczące podatnika i jego spraw tylko w przypadkach i w zakresie dozwolonym ustawą lub umową międzynarodową.

\section{Rozdział 6 \\ Prawo do rzetelnego postępowania administracyjnego i sądowego w sprawach podatkowych}

Art. 13

Rzetelne postępowanie administracyjne i sądowe w sprawach podatkowych

1. Podatnik ma prawo do rzetelnego postępowania administracyjnego i sądowego w sprawach podatkowych, w tym w szczególności prawo do czynnego udziału w tych postępowaniach.

2. Organy podatkowe i sądy rozstrzygając sprawę podatkową mają obowiązek działać w sposób budzący zaufanie, kierując się zasadami bezstronności i równego traktowania. 
3. Organy podatkowe i sądy, rozstrzygając sprawę podatkową, mają obowiązek uwzględniać interes publiczny i słuszny interes podatnika.

\section{Art. 14}

\section{Efektywność postępowania administracyjnego}

1. Organy podatkowe mają obowiązek działać w sprawie wnikliwie i szybko, dążąc do ograniczenia kosztów własnych i kosztów podatnika.

2. Organy podatkowe mają obowiązek podejmować działania umożliwiające osiągnięcie celu ustawowego, które są najmniej uciążliwe dla podatnika.

3. Organy podatkowe mają obowiązek dążyć do załatwienia sprawy we współpracy i porozumieniu z podatnikiem.

\section{Art. 15}

\section{Zakaz wykorzystania materiałów zgromadzonych niezgodnie z prawem}

Materiały zgromadzone sprzecznie z prawem nie stanowią dowodów.

Art. 16

\section{Informacje o podejmowanych przez organy podatkowe czynnościach i rozstrzygnięciach oraz ich przesłankach}

1. Podatnik ma prawo do rzetelnej i zrozumiałej informacji o przesłankach czynności kontrolnych lub wymiarowych podejmowanych wobec niego przez organy podatkowe.

2. Podatnik ma prawo do zawiadomienia o zamiarze podjęcia wobec niego czynności kontrolnych lub wymiarowych, z wyjątkiem przypadków jasno określonych w przepisach ustaw.

3. Podatnik ma prawo wglądu do akt sprawy podatkowej w postępowaniu administracyjnym i sądowym.

4. Podatnik ma prawo do rzetelnej i zrozumiałej informacji o zgromadzonym materiale dowodowym i ustaleniach faktycznych w sprawie.

5. Podatnik ma prawo do rzetelnej i zrozumiałej informacji o przesłankach rozstrzygnięć organów podatkowych i sądów.

\section{Art. 17}

\section{Reprezentacja podatnika}

1. Podatnik ma prawo do bycia reprezentowanym w postępowaniu administracyjnym i sądowym przez zawodowego pełnomocnika lub członka najbliższej rodziny, a w postępowaniu administracyjnym także przez innego pełnomocnika. 
2. Podatnicy, którzy nie posiadają wystarczających środków mają prawo do bezpłatnej pomocy prawnej w postępowaniu administracyjnym i sądowym w zakresie, w jakim jest to niezbędne dla zapewnienia skutecznej ochrony ich praw.

3. Zawodowy pełnomocnik ma prawo zgłaszać ministrowi właściwemu do spraw finansów publicznych oraz Rzecznikowi Praw Obywatelskich przypadki rażącego naruszenia praw podatnika.

\section{Rozdział 7 \\ Prawo do zaskarżenia rozstrzygnięć w sprawach podatkowych}

Art. 18

Informacja o środkach zaskarżenia

Podatnik ma prawo do rzetelnej i zrozumiałej informacji o przysługujących mu środkach zaskarżenia.

Art. 19

Kontrola instancyjna rozstrzygnięcia podatkowego

Podatnik ma prawo do zainicjowania kontroli instancyjnej dotyczącego go rozstrzygnięcia podatkowego.

\section{Art. 20}

\section{Kontrola sądowa rozstrzygnięcia podatkowego}

1. Podatnik ma prawo do zainicjowania kontroli sądowej dotyczącego go rozstrzygnięcia podatkowego przez niezależny sąd w toku dwuinstancyjnego postępowania sądowego.

2. Podatnik ma prawo do zainicjowania kontroli sądowej dotyczącego go rozstrzygnięcia podatkowego, nawet jeśli nie skorzystał z prawa do zainicjowania kontroli instancyjnej.

3. Brak środków na poniesienie kosztów postępowania nie może ograniczać podatnikowi prawa do sądu.

\section{Art. 21}

\section{Zakaz rozstrzygnięcia na niekorzyść skarżącego (zakaz reformationis in peius)}

Wniesienie środka zaskarżenia nie może pogarszać sytuacji podatnika w postępowaniu administracyjnym i sądowym w sprawach podatkowych. 
Art. 22

Prawo do ochrony przed przedwczesną egzekucją

Środki egzekucyjne nie mogą być stosowane przed rozpatrzeniem środków zaskarżenia przeciw wykonalności decyzji.

\section{Rozdział 8 \\ Obowiązek miarkowania sankcji}

Art. 23

Zakaz podwójnego lub nieproporcjonalnego karania

1. Sankcje i odpowiedzialność karna i karna skarbowa są stanowione i nakładane z uwzględnieniem zasady proporcjonalności.

2. Zakazane jest nakładanie podwójnej sankcji (podatkowej i karnej lub karnej skarbowej) za ten sam czyn stanowiący naruszenie normy przepisów prawa podatkowego.

\section{Rozdzial 9 \\ Prawo do naprawienia szkody}

Art. 24

Naprawienie szkody wyrządzonej działaniem lub zaniechaniem organów podatkowych

Podatnik ma prawo do naprawienia szkody wyrządzonej niezgodnym z prawem działaniem lub zaniechaniem organów podatkowych.

\section{Rozdział 10 \\ Kontrola przestrzegania praw podatnika}

\section{Art. 25}

Obowiązek informacyjny sądu administracyjnego

Sąd administracyjny ma obowiązek poinformowania ministra właściwego do spraw finansów publicznych o każdym dostrzeżonym rażącym naruszeniu praw podatnika przez organy podatkowe 
Art. 26

\section{Obowiązek informacyjny ministra właściwego do spraw finansów publicznych}

Minister właściwy do spraw finansów publicznych corocznie składa Sejmowi sprawozdanie o przestrzeganiu praw podatnika, ze szczególnym uwzględnieniem informacji sądów i pełnomocników zawodowych o rażących naruszeniach praw podatnika oraz ocen, wniosków i rekomendacji sformułowanych przez Rzecznika Praw Obywatelskich.

\section{Art. 27}

\section{Obowiązek informacyjny samorządowych organów podatkowych}

Samorządowy organ podatkowy corocznie składa organowi stanowiącemu jednostki samorządu terytorialnego sprawozdanie o przestrzeganiu praw podatnika.

Art. 28

\section{Uprawnienia Rzecznika Praw Obywatelskich}

Rzecznik Praw Obywatelskich, działając w celu zapewnienia skutecznej ochrony praw podatnika, ma prawo wglądu do akt postępowania administracyjnego i sądowego $\mathrm{w}$ sprawach podatkowych, udziału w postępowaniu, żądania wyjaśnień od organów podatkowych i formułowania ocen, wniosków i rekomendacji.

\section{Rozdział 11 \\ Wejście w życie}

Art. 29

Wejście w życie

Ustawa wchodzi w życie po upływie 14 dni od dnia ogłoszenia.

\section{Uzasadnienie}

Proponowana ustawa jest wyrazem założenia, że państwo i samorząd terytorialny są zobowiązane do dbałości o prawa podmiotów, które umożliwiają ich działanie, ponosząc ciężary i świadczenia publiczne, w tym w szczególności podatki. W myśl zasady wzajemnej lojalności, wymagając od podatnika rzetelności w deklarowaniu podstawy opodatkowania i zapłacie należnej kwoty podatku, należy zagwarantować mu przestrzeganie zasady ekonomiczności 
opodatkowania, a także standardów przyzwoitej legislacji i rzetelnego postępowania administracyjnego i sądowego w sprawach podatkowych.

Celem ustawy jest zapewnienie należytej ochrony praw podatników, która każdorazowo wymaga odpowiedniego wyważenia interesu publicznego i prywatnego $\mathrm{w}$ prawie podatkowym. Ustawa ma również na celu podniesienie świadomości społecznej praw podatnika. Cele te zostały wprost wyrażone w Preambule ustawy.

Ustawa wprowadza do polskiego systemu podatkowego nową instytucję, to jest Kartę Praw Podatnika, rozumianą jako tekst normatywny, w którym w zwięzły sposób określone są podstawowe prawa podatników, którym odpowiadają obowiązki organów podatkowych.

Karta Praw Podatnika jest instytucją znaną wielu systemom podatkowym. Posiadanie karty jest międzynarodowym, uznanym standardem, zatem jej brak w polskim systemie podatkowym jest wyrazem nienadążania za najlepszymi praktykami światowymi.

Praktyka międzynarodowa wskazuje, że karty mogą mieć postać przepisów prawa powszechnie obowiązującego, gdy pochodzą od władzy ustawodawczej, lub jednostronnej deklaracji administracji podatkowej. Większość kart w państwach OECD pochodzi od administracji podatkowej i ma charakter niewiążący ${ }^{1}$, przybierając postać niewiążących deklaracji, broszur informacyjnych czy mniej lub bardziej wiążących wewnętrznych regulaminów czy interpretacji ogólnych ${ }^{2}$. Jednakże Doświadczenia innych państw wskazują, że znacznie bardziej efektywne są karty mające formę ustawy $^{3}$ i w wielu państwach karty przybrały formę ustawową. Także w polskich realiach znacznie bardziej efektywna będzie karta przyjęta w formie ustawowej. Siła oddziaływania na praktykę stosowania prawa podatkowego karty o charakterze normatywnym będzie z pewnością większa, niż gdyby poprzestać na dokumencie deklaratywnym pochodzącym od administracji podatkowej. W tym kontekście warto też zauważyć, że polska administracja podatkowa opublikowała na swoich stronach swoistą deklarację praw i obowiązków podatnika ${ }^{4}$. Deklaracja ta nie posiada jednak żadnego

${ }^{1}$ The Practical Protection of Taxpayers' Fundamental Rights, red. P. Baker, P. Pistone, „Cahiers de droit fiscal international” 2015, vol. 100b, s. 75.

${ }^{2}$ M. Cadesky, I. Hayes, D. Russell, A Model Taxpayer Charter. Preliminary Report. Towards Greater Fairness in Taxation, London 2013, s. 162.

${ }^{3}$ Ibidem, s. 20, 26, 33.

${ }^{4}$ Ministerstwo Finansów, Uprawnienia i obowiązki podatnika, http://www.finanse. mf.gov.pl/abc-podatkow/uprawnienia-i-obowiazki-podatnika (dostęp: 18.01.2018). 
waloru prawnego, a podatnicy w dużej mierze nie wiedzą o niej. W konsekwencji, deklaracja ta nie ma żadnego znaczenia w praktyce. Ponadto, tylko forma ustawowa, jako wyraz pewnego samozwiązania ustawodawcy, daje nadzieję na poprawę praktyki tworzenia prawa podatkowego.

Karty najczęściej przyjmują formę odrębnych dokumentów (normatywnych lub deklaratywnych). Niekiedy za kartę uznaje się dostatecznie wyodrębnioną część ogólnych ustaw podatkowych, skupiającą przepisy dotyczące podstawowych praw (i obowiązków) podatników. Nie każdy podatnik ma jednak świadomość obowiązywania, zawartości i roli takich aktów prawnych jak Ordynacja podatkowa. Ponadto podatnicy często unikają sięgania bezpośrednio do aktów prawnych, zniechęceni ich dużą objętością, stopniem złożoności i szczególnym, trudnym niekiedy do zrozumienia, językiem. Dlatego lepszym rozwiązaniem wydaje się karta w formie odrębnego dokumentu, mającego charakter normatywny, lecz znacznie krótszego i napisanego prostszym językiem niż inne akty prawne z zakresu prawa podatkowego.

Próbę włączenia postanowień typowych dla kart do treści Ordynacji podatkowej podjęła Komisja Kodyfikacyjna Ogólnego Prawa Podatkowe$\mathrm{go}^{5}$, i choć inicjatywa ta zasługuje na pozytywną ocenę, najlepszym dla Polski rozwiązaniem jest odrębny dokument normatywny, przyjęty już teraz i czerpiący z wyników prac Komisji Kodyfikacyjnej, a także z wcześniejszych projektów kart, deklaracji i przepisów ogólnych prawa podatkowego opracowanych przez przedstawicieli nauki i praktyki prawa podatkowego ${ }^{6}$. Ze względu na szeroką reprezentację grup zainteresowanych prawem podatkowym w pracach nad projektem Deklaracji Praw Podatnika podpisanej dnia 18 maja 2011 r. pod patronatem Krajowej Rady Doradców Podatkowych ${ }^{7}$ właśnie ten dokument przyjęto jako punkt wyjścia w pracach nad

${ }^{5}$ Zob. Komisja Kodyfikacyjna Ogólnego Prawa Podatkowego, Projekt $z$ dnia 6 października 2017 r. ustawy Ordynacja podatkowa, art. 14-34, http://www.mf.gov.pl/ministerstwofinansow/dzialalnosc/ciala-kolegialne/komisja-kodyfikacyjna-ogolnego-prawa-podatko wego/prace-komisji (dostęp: 18.01.2018).

${ }^{6}$ Zob. A. Mariański, Projekt Deklaracji Praw Podatnika, Oficyna Prawa Polskiego, www.pit.pl/att/Projekty_Karty_Praw_Podatnika.doc (dostęp: 18.01.2018); D. Szubielska, Projekt Karty Praw Podatnika, Oficyna Prawa Polskiego, www.pit.pl/att/Projekty_Karty_Praw_Podatnika.doc (dostęp: 18.01.2018); T. Dębowska-Romanowska, Projekt Karty Praw Uczciwego Podatnika, Oficyna Prawa Polskiego, www.pit.pl/att/Projekty_Karty_ Praw_Podatnika.doc (dostęp: 18.01.2018); CDiSP, Projekt przepisów ogólnych Ordynacji Podatkowej, „Kwartalnik Prawa Podatkowego” 2001, nr 3-4.

${ }^{7}$ Zob. W. Konieczny, S. Babiarz, B. Dauter, B. Brzeziński, P. Karwat, T. Michalik, A. Olesińska, D. Szczygieł, D. Szubielska, Deklaracja Praw Podatnika, podpisana przez szerokie 
projektem ustawy, jednocześnie czerpiąc z rozwiązań zawartych w projekcie Ordynacji podatkowej oraz w projektach przedstawionych przez poszczególnych przedstawicieli nauki i praktyki prawa podatkowego. Źródłem inspiracji był też Kodeks postępowania administracyjnego ${ }^{8}$. Sięgnięto również do rezultatów prac międzynarodowych ${ }^{9}$. W projekcie uwzględniono też uwagi zgłoszone przez uczestników dwóch konferencji „Karta Praw Podatnika”, które odbyły się w Łodzi w dniu 12 marca 2018 r. i w Warszawie w dniu 26 marca 2019 r.

W obliczu licznych i częstych zmian w polskim prawie podatkowym, niekiedy godzących w prawa podatnika oraz niestety nadal występujących naruszeń praw podatnika w procesie stosowania prawa, wprowadzenie karty jako nowego instrumentu wzmacniającego ochronę tych praw, zarówno na etapie tworzenia, jak i stosowania prawa podatkowego, jest obecnie konieczne. Prawo podatkowe silnie ingeruje w prawa podatnika, a organ podatkowy, również jako gospodarz postępowania podatkowego, dysponuje naturalną przewagą nad podatnikiem. Instrumenty takie jak Karta Praw Podatnika są konieczne, aby łagodzić skutki istniejącej nierównowagi oraz zwiększać zaufanie podatnika do państwa, oparte na przekonaniu, że państwo przywiązuje należytą wagę do ochrony praw podatnika.

Podstawowym zadaniem proponowanej karty nie jest przyznanie podatnikom nowych praw, bo te wynikają już z Konstytucji, a także z ustaw szczegółowych prawa proceduralnego i materialnego. Karta ma za zadanie wzmocnić ochronę tych praw, poprzez usystematyzowanie ich w formie zasad systemu prawa podatkowego, to jest norm zawartych bezpośrednio w prawie pozytywnym i cechujących się szczególną doniosłością dla systemu prawa podatkowego jako całości, poszczególnych jego części i instytucji. Normy zapisane w karcie, $\mathrm{z}$ istoty swej bardziej ogólne, podlegają uszczegółowieniu w innych ustawach, w tym w szczególności w Ordynacji podatkowej. Normy zapisane w karcie należy stosować łącznie z innymi

grono przedstawicieli nauki i praktyki prawa podatkowego w dniu 18 maja $2011 \mathrm{r}$. podczas Dnia Ochrony Praw Podatnika w Warszawie, https://krdp.pl//aktualnosciall.php/9/1643 (dostęp: 18.01.2018).

${ }^{8}$ Ustawa z dnia 14 czerwca 1960 r. Kodeks postępowania administracyjnego, tekst jedn. Dz.U. z 2018 r., poz. 2096.

${ }_{9}^{9}$ M. Cadesky, I. Hayes, D. Russell, A Model Taxpayer Charter...; zob. też Komisja Europejska, Wytyczne dotyczące wzoru Kodeksu podatników Unii Europejskiej, Bruksela 2016, s. 1, https://ec.europa.eu/taxation_customs/sites/taxation/files/guidelines_for_a_ model_for_a_european_taxpayers_code_pl.pdf(dostęp: 7.11.2017). 
normami albo bezpośrednio i samodzielnie. Normy te powinny stanowić też kontekst interpretacyjny dla całego systemu prawa podatkowego, wszystkich pozostałych przepisów prawa podatkowego.

W niektórych obszarach proponowana karta uzupełnia dotychczasowy katalog praw podatnika albo wyraża wprost prawa, których obowiązywanie obecnie jest niekiedy kwestionowane, choć nie powinno być. Jednakże nawet wówczas, gdy proponowana karta powtarza jedynie prawa, które wynikają już z innych przepisów, ma do odegrania ważną rolę porządkującą, wzmacniającą oraz edukacyjną. Karta w formie krótkiej ustawy ułatwi podatnikom, szczególnie tym nie korzystającym z usług profesjonalnych pełnomocników, odnalezienie i powołanie konkretnej podstawy prawnej dla ochrony ich praw. $\mathrm{Z}$ analizy praktyki wynika bowiem, że niekiedy niemożliwość wskazania konkretnego przepisu będącego źródłem danego prawa, istotnie osłabia ochronę tego prawa.

Ustanowione w karcie liczne obowiązki informacyjne są wyrazem roli edukacyjnej, jaką karta ma odegrać wobec podatników i przedstawicieli administracji podatkowej.

Rozdział pierwszy ustawy zawiera postanowienia wstępne.

W artykule pierwszym wyznaczono zakres podmiotowy ustawy, wskazując, że jej unormowania stosuje się nie tylko do podatników, lecz również do innych podmiotów, których prawa i obowiązki są regulowane przepisami prawa podatkowego, przykładowo wymieniając płatników, inkasentów, osoby trzecie odpowiedzialne za zaległości podatkowe oraz następców prawnych w prawie podatkowym. Sprecyzowano również, że ilekroć w ustawie mowa jest o podatniku, rozumie się przez to również inne podmioty, których prawa i obowiązki są regulowane przepisami prawa podatkowego. Przyjęcie otwartego katalogu podmiotów objętych postanowieniami ustawy było konieczne dla skutecznej ochrony praw wszystkich podmiotów ponoszących koszty i konsekwencje obowiązywania unormowań podatkowych, czy to w postaci obowiązku poniesienia ciężaru podatku, odpowiedzialności podatkowej, czy obowiązków instrumentalnych.

W artykule drugim wprowadzono podstawowe obowiązki informacyjne w zakresie praw podatnika dla organów podatkowych: obowiązek publikowania treści ustawy Karta Praw Podatnika na stronach internetowych organów podatkowych oraz obowiązek przekazywania podatnikowi egzemplarza ustawy przy wszczęciu postępowania podatkowego, kontroli podatkowej lub kontroli celno-skarbowej. Wprowadzenie tych obowiązków 
jest konieczne dla realizacji celu edukacyjnego karty i podniesienia świadomości obowiązywania prawa podatnika zarówno wśród administracji podatkowej, jak i podatników.

W rozdziale drugim uregulowano prawo do dobrego prawodawstwa podatkowego, którego korelatem jest obowiązek prawodawcy tworzenia prawa podatkowego spełniającego kryteria „dobrego prawa podatkowego”.

Jak wynika $\mathrm{z}$ artykułu trzeciego, dobre prawo podatkowe, to prawo tworzone $\mathrm{z}$ poszanowaniem konstytucyjnie określonych praw i wolności ekonomicznych oraz z uwzględnieniem zarówno interesu publicznego jak i prywatnego. W prawie podatkowym, które jest dziedziną prawa szczególnie ingerencyjną, interesy te powinny być odpowiednio wyważone. Odpowiedniemu wyważeniu tych interesów służy w szczególności konsultowanie projektów przepisów prawa podatkowego z podatnikami, przedstawicielami organizacji społecznych, samorządowych i gospodarczych oraz samorządów zawodowych, a także uwzględnianie słusznych postulatów tych grup interesów. Prawo podatkowe musi być tworzone z poszanowaniem istoty prawa własności, zasady ochrony źródeł podatku i zasady zdolności płatniczej. Nie może zagrażać egzystencji podatnika i podejmowaniu oraz kontynuowaniu działalności zarobkowej, w tym działalności gospodarczej.

Dobre prawo podatkowe musi gwarantować podatnikowi pewność, o czym stanowi artykuł czwarty. Pewność w prawie podatkowym to ochrona praw nabytych i interesów w toku, a także upływ odpowiednio długiego czasu między urzędowym ogłoszeniem przepisu, a jego wejściem w życie, tak by podatnik mógł przygotować się do nowego stanu prawnego, odpowiednio układając swoje sprawy. Długość tego okresu powinna zawsze zależeć od tego, jak liczne i jak poważne zmiany są wprowadzane. Pewność prawa to również zakaz działania prawa wstecz, z wyjątkiem gdy nowe prawo działa na korzyść podatnika. O ile dopuszczalne jest wprowadzenie z mocą wsteczną unormowań, które regulują sytuację podatnika w sposób bardziej dla niego korzystny niż dotychczasowe normy, to niedopuszczalne w demokratycznym państwie prawnym jest wprowadzanie unormowań, które określałyby w sposób mniej dla podatnika korzystny skutki podatkowe zdarzeń przeszłych. Podatnik nie może też być zaskakiwany zmieniającym się sposobem stosowania i rozumienia przepisów prawa podatkowego przez organy podatkowe. Artykuł czwarty stanowi zatem także, że organy podatkowe bez uzasadnionej przyczyny nie mogą odstępować od utrwalonej praktyki rozstrzygania spraw w takim samym stanie faktycznym 
i prawnym. Pewność w prawie podatkowym to również prawo podatnika do stabilizacji stosunków prawnych przez przedawnienie następujące w rozsądnym i przewidywalnym czasie. Podatnik, który szczególnie w ramach systemu samoobliczenia podatku, ponosi ryzyko prawidłowego odczytania i zastosowania niejednokrotnie zawiłych i niejasnych przepisów prawa podatkowego, ma prawo w stosownym czasie uzyskać pewność, co do tego, że sposób realizacji przez niego obowiązków wynikających z przepisów prawa podatkowego nie będzie kwestionowany i że nie poniesie już negatywnych konsekwencji nieprawidłowości w tym zakresie. Brak przewidywalności terminu przedawnienia, czyni z przedawnienia instytucję iluzoryczną, dlatego $\mathrm{w}$ artykule czwartym podkreślono prawo podatnika do przedawnienia następującego w przewidywalnym terminie.

Artykuł piąty stanowi, że dobre prawo podatkowe musi być jawne dla podatnika. Podatnik w każdym czasie musi mieć możliwość zapoznania się z treścią przepisów prawa podatkowego w aktualnym brzmieniu. W obliczu częstych zmian przepisów prawa podatkowego, konieczna jest urzędowa publikacja ujednoliconych tekstów aktów prawnych z zakresu prawa podatkowego. Obowiązkiem tym obciążono ministra właściwego do spraw finansów publicznych. Jawność dla podatnika to również tworzenie i przyjmowanie przepisów prawa podatkowego w ramach jawnych procedur prawodawczych. Wśród składowych jawności procesu tworzenia i przyjmowania przepisów, szczególną uwagę należy zwrócić na publikowanie rządowych założeń i projektów przepisów prawa podatkowego $\mathrm{z}$ odpowiednim wyprzedzeniem $\mathrm{w}$ celu poddania ich konsultacjom publicznym. Jak już wskazano, konsultacje publiczne mogą przyczynić się do odpowiedniego wyważenia interesu publicznego i prywatnego. Ponadto publikacja wspomnianych założeń i projektów jest składową pewności prawa podatkowego, jeśli podatnik $\mathrm{z}$ odpowiednim wyprzedzeniem może się zapoznać $\mathrm{z}$ planowanymi zmianami w zakresie prawa podatkowego. Istotną rolę ogrywa również zapewnienie jawności debat parlamentarnych oraz debat w organach stanowiących jednostek samorządu terytorialnego.

Dobre prawo podatkowe musi być komunikatywne: zrozumiałe i jasne. Artykuł szósty wprost stanowi o prawie podatnika do zrozumiałego i jasnego prawa podatkowego. Dla prawidłowego funkcjonowania systemu podatkowego oraz dla ochrony podatników przed skutkami obowiązywania niedostatecznie jasnych i zrozumiałych przepisów, organy podatkowe, jako przedstawiciele państwa i jednostek samorządu terytorialnego ponoszących odpowiedzialność za jakość obowiązujących przepisów, muszą 
wspierać podatników w wykonywaniu ich obowiązków i praw, w szczególności udzielając informacji o prawidłowym sposobie rozumienia i stosowania przepisów. Jeśli podatnik zastosuje się do informacji udzielonej przez organ podatkowy w przewidzianej prawem formie, nie może ponieść $\mathrm{z}$ tego powodu szkody. W projektowanych przepisach mowa o informacjach udzielonych w przewidzianej w prawie formie, na przykład $\mathrm{w}$ formie interpretacji indywidualnej, interpretacji ogólnej, objaśnień podatkowych, aby odpowiednio wyważyć interes publiczny i prywatny, a zarazem zwiększyć pewność, co do przypadków, gdy ochrona przysługuje, szczególnie, że skutki ochronne określono dość szeroko. W szczególności zastosowanie się do udzielonej w przewidzianej prawem formie informacji, którego skutkiem była nieprawidłowa realizacja obowiązków nałożonych przepisami prawa podatkowego, nie może być podstawą do zastosowania żadnych sankcji podatkowych, karnych lub karnych skarbowych, ani żądania odsetek od zaległości podatkowych. Ponadto, całą odpowiedzialność za odpowiednią jakość przepisów podatkowych ponosi prawodawca, a zatem niedające się usunąć wątpliwości co do treści normy prawa podatkowego muszą być rozstrzygane na korzyść podatnika, a niezrozumiały przepis prawa podatkowego nie może być podstawą zastosowania sankcji podatkowych, karnych lub karnych skarbowych.

W rozdziale trzecim uregulowano prawo podatnika do zapłaty podatku w wysokości wynikającej z ustaw podatkowych.

Artykuł siódmy dotyczy prawa do zapłaty podatku w prawidłowej wysokości i do zwrotu należnej nadpłaty. Podatnik ma prawo do tego, by płacić tylko taką kwotę podatku, jaka wynika z prawidłowo intepretowanych i stosowanych przepisów prawa podatkowego, co oznacza kwotę nie większą i nie mniejszą niż określono w przepisach, również z uwzględnieniem przewidzianych prawem ulg i zwolnień oraz zastosowaniem innych przewidzianych przepisami możliwości obniżenia wysokości podatku, o czym mowa w kolejnym, ósmym artykule. Dla realizacji prawa do zapłaty podatku w wysokości wynikającej z ustaw podatkowych, konieczne jest, by podatnik mógł skorygować złożoną deklarację lub zainicjować postępowanie mające na celu stwierdzenie, czy doszło do powstania nadpłaty. Jeśli doszło do powstania nadpłaty, jej zwrot powinien nastąpić w rozsądnym terminie.

Przesłanki zastosowania ulg i zwolnień powinny być jasno i precyzyjnie określone w przepisach, co wyrażono w artykule ósmym. Spełnienie 
tych przesłanek, daje podatnikowi prawo do skorzystania z ulg i zwolnień i organy podatkowe nie mogą w sposób arbitralny pozbawiać podatnika tego prawa, kierując się nieprawidłowym założeniem, że ulga czy zwolnienie stanowi rozwiązanie wyjątkowe, a interes publiczny wymaga pobrania podatku w możliwie najwyższej kwocie. Interes publiczny wymaga bowiem pobrania podatku tylko w prawidłowej kwocie, wynikającej z przyjętych w ramach mechanizmów demokratycznych przepisów podatkowych. Prawa podatnika i wierzyciela podatkowego, czyli państwa lub jednostki samorządu terytorialnego, muszą pozostawać $\mathrm{w}$ równowadze, również czasowej. Prawo do ulg i zwolnień i korzystania z innych przewidzianych przepisami możliwości obniżenia wysokości podatku musi zatem przysługiwać podatnikowi w każdym czasie, choć nie dłużej niż do czasu przedawnienia zobowiązania podatkowego. W tym samym bowiem czasie organy podatkowe mają prawo do egzekwowania obowiązków podatnika. Prawa do skorzystania z ulg i zwolnień nie może ograniczać nadmierny formalizm, czy terminy na wyrażenie woli skorzystania z ulgi krótsze niż termin przedawnienia zobowiązania podatkowego. Odpowiednie wyważenie interesu publicznego i prywatnego wymaga też tego, by podatnik miał prawo do ulgi w zapłacie zobowiązań podatkowych lub do umorzenia zaległości podatkowej, jeśli będą za tym przemawiać wartości konstytucyjne, w tym w szczególności konieczność ochrony godności jednostki, ochronnych rodziny, ochrony minimum egzystencji, a także zasada ochrony źródeł podatku. W niektórych bowiem sytuacjach, rezygnacja przez państwo lub jednostkę samorządu terytorialnego z należności podatkowej, choć stanowi odstępstwo od zasady powszechności opodatkowana, lepiej realizuje wartości konstytucyjne i interes publiczny.

Podatnik jako słabsza, podporządkowana strona stosunku podatkowoprawnego, ma prawo do domniemania rzetelności i dobrej wiary, o czym mowa w rozdziale czwartym. Prawo podatkowe jako gałąź prawa o charakterze ingerencyjnym, podobnie jak prawo karne, musi w tym zakresie ustanawiać domniemania służące ochronie praw podmiotu podporządkowanego.

W artykule dziewiątym wprost postanowiono, że deklarację złożoną przez podatnika należy uważać za prawidłową, dopóki organ podatkowy zgodnie $\mathrm{z}$ regułami postępowania dowodowego i prawidłowego rozumowania, nie wykaże jej nieprawidłowości. Również dokonanie skutecznej korekty deklaracji, pozbawia poprzednio złożoną deklarację waloru 
prawidłowości. Ponieważ złożenie prawidłowej deklaracji podatkowej jest tylko jednym $z$ obowiązków podatnika, w ustępie pierwszym wprowadzono szersze domniemanie, że podatnik prawidłowo wywiązuje się z obowiązków wynikających z przepisów prawa podatkowego. Domniemanie to może zostać obalone, jeśli organ podatkowy wykaże, że obowiązki nie zostały prawidłowo wykonane. Artykuł dziewiąty stanowi też o rozstrzyganiu na korzyść podatnika wątpliwości co do stanu faktycznego, których nie udało się usunąć mimo przeprowadzenia wyczerpującego postępowania dowodowego. Unormowanie to nie znajdzie zastosowania, jeśli przepisy wprost wymagają od podatnika wykazania określonych faktów. Wówczas zgromadzenie dowodów umożliwiających rozstrzygnięcie wątpliwości co do tych faktów jest bowiem obowiązkiem podatnika.

Artykuł dziesiąty wprowadza nową jakość normatywną: uregulowane wprost domniemanie działania podatnika w dobre wierze, a zatem domniemanie, że podatnik nie wiedział i mimo dochowania odpowiedniej staranności nie mógł wiedzieć o nieprawidłowościach w realizacji obowiązków z zakresu prawa podatkowego przez niego bądź jego kontrahentów, czy o oszustwach podatkowych popełnionych przez tych drugich. Domniemanie to zostaje obalone, jeśli organ podatkowy wykaże, że podatnik działał w złej wierze. Punktem wyjścia w każdym postępowaniu powinno zatem być przyjęcie założenia dobrej wiary podatnika i określanie skutków podatkowych zgodnie z tym założeniem. Dopiero wykazanie zgodnie $\mathrm{z}$ regułami postępowania dowodowego i prawidłowego rozumowania, że podatnik działał w złej wierze, uprawnia organy podatkowe do określania skutków podatkowych będących następstwem działania przez podatnika w złej wierze. Brak takiego domniemania wyrażonego wprost w dotychczas obowiązujących przepisach stanowi istotne zagrożenie dla podatnika, choć samo obowiązywanie takiego domniemania nie powinno budzić wątpliwości w demokratycznym państwie prawnym, w którym w zakresie postępowania podatkowego obowiązuje domniemanie prawidłowości zadeklarowanej przez podatnika kwoty podatku, a także zasada prawdy obiektywnej.

W rozdziale piątym uregulowano bardzo ważne prawo do prywatności. Artykuł jedenasty poświęcono kwestii prawa do ochrony danych oraz prawa dostępu podatnika do dotyczących go danych będących w posiadaniu organów podatkowych. Organy podatkowe mogą gromadzić i przetwarzać jedynie takie informacje dotyczące podatnika i jego spraw, które 
pozostają w odpowiednim związku z realizacją jego obowiązków podatkowych i praw z tego zakresu. Obowiązuje zatem zakaz gromadzenia i przetwarzania danych „na zapas”, bez odpowiedniego uzasadnienia przez powiązanie z realizacją obowiązków podatkowych lub korzystania z praw przez podatnika. Organy podatkowe mogą wykorzystywać informacje dotyczące podatnika i jego spraw tylko w zakresie dozwolonym prawem, wskazując podstawę prawną dla każdego przypadku wykorzystania tych danych. Ochrona słusznego interesu podatnika wymaga, by miał on dostęp do informacji dotyczących jego i jego spraw gromadzonych i przetwarzanych przez organy podatkowe.

W artykule dwunastym nałożono na organy podatkowe obowiązek zachowania informacji dotyczących podatnika i jego spraw w tajemnicy. Przekazanie innym podmiotom informacji dotyczących podatnika i jego spraw jest dozwolone tylko $\mathrm{w}$ przypadkach i w zakresie przewidzianym w przepisach ustaw i umów międzynarodowych.

Rozdział szósty dotyczy prawa do rzetelnego postępowania administracyjnego i sądowego w sprawach podatkowych.

W artykule trzynastym wyrażono prawo podatnika do rzetelnego postępowania administracyjnego i sądowego w sprawach podatkowych, co wymaga przestrzegania $\mathrm{w}$ tych postępowaniach wszystkich reguł proceduralnych oraz prawidłowej interpretacji i zastosowania przepisów proceduralnych i materialnych. Wymaga to również stałego, odpowiedniego wyważania interesu publicznego i słusznego interesu podatnika. Organy podatkowe i sądy mają obowiązek działać w sposób budzący zaufanie, w sposób racjonalny i przewidywalny oraz kierując się zasadami bezstronności i równego traktowania. Podatnik ma zaś prawo do czynnego udziału w postępowaniu administracyjnym i sądowym w całym jego toku.

Jak stanowi artykuł czternasty, postępowanie administracyjne w sprawach podatkowych musi być efektywne, zgodnie z zasadami ekonomiki procesowej. Organy podatkowe mają obowiązek działać w sprawie wnikliwie i szybko, dążąc zarówno do ograniczenia kosztów własnych, jak i kosztów ponoszonych przez podatnika. Nadmiernie długie oczekiwanie na rozstrzygnięcie sprawy podatkowej stanowi zagrożenie zarówno dla słusznych interesów podatnika, jak i dla interesów wierzyciela podatkowego, czyli państwa czy jednostki samorządu terytorialnego. Ponadto, organy podatkowe, w myśl zasady proporcjonalności, mają obowiązek podejmować te działania umożliwiające osiągnięcie celu ustawowego, które są najmniej 
uciążliwe dla podatnika. Ważnym aspektem prawa do efektywnego postępowania administracyjnego, jest obowiązek dążenia do załatwienia sprawy we współpracy i porozumieniu z podatnikiem, w każdym przypadku, gdy pozwalają na to przepisy, co służy realizacji odpowiednio wyważonych interesu publicznego i prywatnego.

W artykule piętnastym wyraźnie postanowiono, że materiały zgromadzone niezgodnie $\mathrm{z}$ przepisami, nie mogą stanowić dowodów $\mathrm{w}$ postępowaniu w sprawach podatkowych. To bardzo ważne unormowanie o charakterze gwarancyjnym, odpowiadające wymogom demokratycznego państwa prawnego. Państwo i jednostka samorządu terytorialnego nie mogą odnosić korzyści procesowych z działań niezgodnych z prawem.

Artykuł szesnasty dotyczy bardzo istotnego prawa podatnika do uzyskania informacji o podejmowanych wobec niego przez organy podatkowe czynnościach i rozstrzygnięciach oraz ich przesłankach. Podatnik ma prawo do uzyskania rzetelnej, a więc zgodnej z prawdą, oraz zrozumiałej informacji o przesłankach, czyli podstawach prawnych i faktycznych czynności kontrolnych i wymiarowych podejmowanych wobec niego przez organy podatkowe. Podatnika należy zawiadamiać o zamiarze podjęcia wobec niego czynności kontrolnych czy wymiarowych, przy czym wymóg ten nie może być bezwzględny, gdyż w wyjątkowych przypadkach jasno określonych w przepisach ustaw prowadzenie działań kontrolnych bez wcześniejszego zawiadomienia może okazać się konieczne dla zabezpieczenia interesu publicznego. Podatnik ma też prawo wglądu do akt sprawy w postępowaniu administracyjnym i sądowym oraz do rzetelnej i zrozumiałej informacji o zgromadzonym materiale dowodowym i dokonanych na jego podstawie ustaleniach faktycznych. Podatnik ma też prawo do rzetelnej i zrozumiałej informacji o przesłankach faktycznych i prawnych rozstrzygnięć organów podatkowych i sądów, czego wyrazem będzie prawidłowe, zgodne z prawdą, wyczerpujące i zrozumiałe uzasadnianie rozstrzygnięć.

$\mathrm{W}$ artykule siedemnastym postanowiono, że podatnik ma prawo do bycia reprezentowanym w postępowaniu administracyjnym i sądowym w sprawach podatkowych przez pełnomocnika zawodowego lub członka najbliższej rodziny. W postępowaniu administracyjnym ma też prawo do bycia reprezentowanym przez innego pełnomocnika. Bardzo istotne dla realizacji prawa do bycia reprezentowanym, stanowiącego element prawa do obrony, będącego standardem w demokratycznym państwie prawnym, jest zapewnienie podatnikom, którzy nie posiadają wystarczających środków, bezpłatnej pomocy prawnej w postępowaniu administracyjnym i sądowym. 
Dostrzegając istotną rolę, jaką dla prawidłowego funkcjonowania systemu podatkowego odgrywają pełnomocnicy profesjonalni, w artykule siedemnastym wprowadzono nowe uprawnienie dla tej kategorii pełnomocników: prawo zgłaszania ministrowi właściwemu do spraw finansów publicznych oraz Rzecznikowi Praw Obywatelskich dostrzeżonych przypadków rażącego naruszenia praw podatnika. Uprawnienie to koreluje z uregulowanym $\mathrm{w}$ artykule dwudziestym szóstym obowiązkiem informacyjnym ministra właściwego do spraw finansów publicznych, który w sprawozdaniu o przestrzeganiu praw podatnika składanym corocznie Sejmowi ma obowiązek uwzględnić informacje o naruszeniach przekazane przez pełnomocników.

Rozdział siódmy poświęcono prawu do zaskarżenia rozstrzygnięć w sprawach podatkowych.

Aby podatnik mógł skutecznie korzystać z przysługujących mu środków zaskarżenia, ma prawo do uzyskania rzetelnej i zrozumiałej informacji o tych środkach, o czym stanowi artykuł osiemnasty.

Artykuł dziewiętnasty stanowi, że podatnik ma prawo zainicjowania kontroli instancyjnej dotyczącego go rozstrzygnięcia, co oznacza prawo do wniesienia środka zaskarżenia, skutkującego ponownym rozpatrzeniem i rozstrzygnięciem sprawy przez organ podatkowy wyższego stopnia.

Podatnik ma też prawo do zainicjowania kontroli sądowej dotyczącego go rozstrzygnięcia przez niezależny sąd w toku dwuinstancyjnego postępowania sądowego. W artykule dwudziestym wskazano też, że podatnik może zaskarżyć rozstrzygnięcie podatkowe bezpośrednio do sądu, z pominięciem kontroli instancyjnej, co potencjalnie może prowadzić do szybszego ostatecznego rozstrzygnięcia sprawy. Brak środków na poniesienie kosztów postępowania, w tym w szczególności uiszczenie wpisów sądowych, czy poniesienie kosztów reprezentacji przez zawodowego pełnomocnika, nie może ograniczać podatnikowi prawa do sądu. W uzasadnionych przypadkach, należy zatem zwolnić podatników z kosztów postępowania sądowego.

Aby podatnik mógł w pełni korzystać ze swojego prawa do zaskarżenia rozstrzygnięć podatkowych, należy, jak uczyniono w artykule dwudziestym pierwszym, wprost postanowić, że wniesienie środka zaskarżenia nie może pogarszać sytuacji podatnika w postępowaniu administracyjnym i sądowym. Zatem Organ podatkowy i sąd nie mogą orzec na niekorzyść podatnika, to jest ograniczyć jego uprawnień albo rozszerzyć jego obowiązków względem zakresu uprawnień lub obowiązków określonych w zaskarżonym rozstrzygnięciu. 
Dla efektywności środków zaskarżenia przeciw wykonalności decyzji, bardzo ważne jest, by środki egzekucyjne nie były stosowane przed rozpatrzeniem wniesionych środków zaskarżenia na wykonalność decyzji. Stanowi o tym artykuł dwudziesty drugi.

W rozdziale ósmym uregulowano prawo do miarkowania sankcji.

Artykułem dwudziestym trzecim ustanowiono zakaz podwójnego lub nieproporcjonalnego karania, stanowiąc, że sankcje i odpowiedzialność karna i karna skarbowa muszą uwzględniać zasadę proporcjonalności. Zakazano też stosowania podwójnej sankcji (podatkowej i karnej lub karnej skarbowej) za ten sam czyn stanowiący naruszenie normy prawa podatkowego.

Rozdział dziewiąty dotyczy prawa do naprawienia szkody poniesionej przez podatnika.

Artykuł dwudziesty czwarty stanowi, że podatnik ma prawo do naprawienia zarówno tej szkody, która powstała wskutek niezgodnego z prawem działania, jak i zaniechania organów podatkowych. Szczególnie istotne jest wyrażenie prawa do naprawienia szkody wynikającej z niezgodnego z prawem zaniechania organów podatkowych, a więc niepodjęcia przez nie przewidzianych prawem działań czy rozstrzygnięć albo niepodjęcia tych działań lub rozstrzygnięć w odpowiednim czasie.

Dziesiąty rozdział ustawy poświęcono zagadnieniu kontroli przestrzegania praw podatnika. Aby Karta była skutecznym instrumentem ochrony praw podatnika należy wprowadzić efektywne mechanizmy kontroli społecznej i politycznej, motywując tym samym zarówno organy podatkowe, jak i samego prawodawcę do przestrzegania postanowień Karty w procesie stosowania, ale i tworzenia przepisów prawa podatkowego.

W artykule dwudziestym piątym, na sądy administracyjne nałożono obowiązek informowania ministra właściwego do spraw finansów publicznych o każdym dostrzeżonym rażącym naruszeniu praw podatnika przez organy podatkowe.

Powyższy obowiązek, podobnie jak prawo do przekazywania takich informacji przyznane pełnomocnikom zawodowym na mocy artykułu siedemnastego, jest skorelowany z nałożonym na ministra właściwego do spraw finansów publicznych obowiązkiem przestawiania corocznie Sejmowi sprawozdania o przestrzeganiu praw podatnika. W sprawozdaniu tym 
minister musi w szczególności uwzględnić informacje o rażących naruszeniach przekazane przez sądy i pełnomocników zawodowych, a także oceny, wnioski i rekomendacje sformułowane przez Rzecznika Praw Obywatelskich. Mowa o tym w artykule dwudziestym szóstym.

Artykuł dwudziesty siódmy nakłada podobny obowiązek sprawozdawczy na samorządowe organy podatkowe. Organy te corocznie składają organowi stanowiącemu jednostki samorządu terytorialnego sprawozdanie o przestrzeganiu praw podatnika.

W artykule dwudziestym ósmym uregulowano uprawnienia Rzecznika Praw Obywatelskich. Rzecznik Praw Obywatelskich, działając w celu zapewnienia skutecznej ochrony praw podatnika, ma prawo wglądu do akt postępowania administracyjnego i sądowego w sprawach podatkowych, udziału w postępowaniu, żądania wyjaśnień od organów podatkowych i formułowania ocen, wniosków i rekomendacji.

Rozdział jedenasty dotyczy wejścia w życie.

Jak postanowiono w artykule dwudziestym dziewiątym, ustawa wchodzi w życie w terminie 14 dni od ogłoszenia. Ten termin jest związany $\mathrm{z}$ istotną rolę gwarancyjną, jaką ustawa ma do odegrania w systemie podatkowym. 